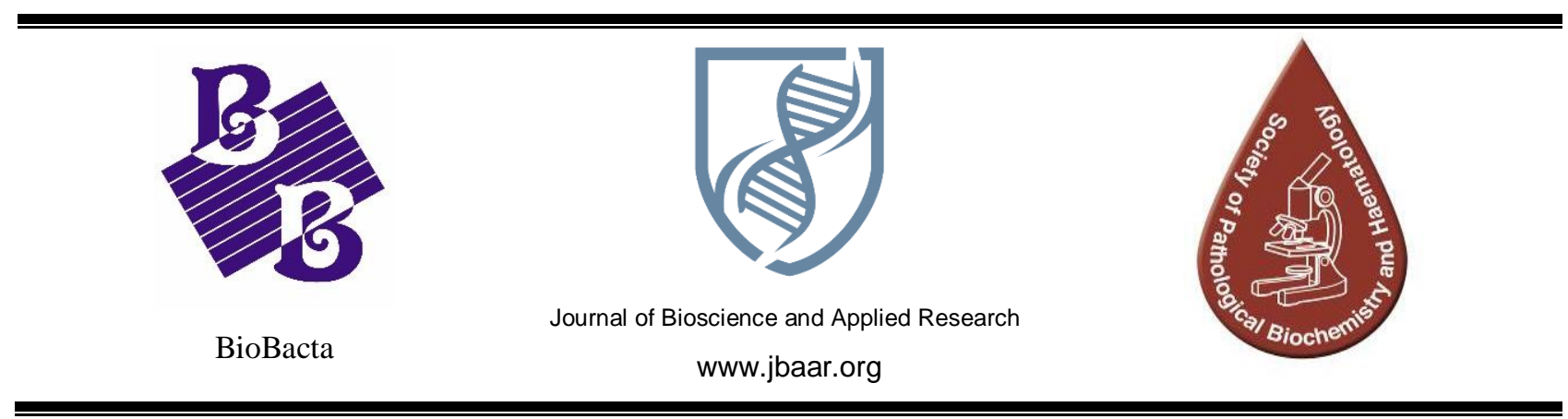

\title{
Measurement of the concentration of calcium in the serum of diabetic patients in Missan province, Iraq
}

Farah Mjbali Jabber

College of Pharmacy, University of Missan, Iraq

Received: March 10, 2018. Accepted: June 5, 2018. Published: June 14, 2018

DOI: $10.21608 /$ JBAAR. 2018.130272

\begin{abstract}
This study was conducted to measure the concentration of calcium in the serum of diabetic patients, calcium is one of the trace elements, by studying 50 samples representing the group of patients divided into three groups by age groups, the first group of age (4-20) years, the second group of the age of (21-50) years, the third group age (51-75) Year of both sexes compared to 30 samples taken from healthy individuals as a control group. The concentration of calcium was measured for patients and healthy people.
\end{abstract}

Aim:- This study aimed to measure and compare the serum levels of calcium in normal individuals and diabetic patients.

Key Words:- Calcium, Diabetes mellitus, Antioxidants

\section{Introduction}

Diabetes is a group of metabolic disorders characterized by high blood sugar levels ${ }^{(\mathbf{1})}$, which result from defects in the ability of the body to produce or use insulin, a condition determined primarily by high blood sugar, which is the metabolic disorder of carbohydrates, it is usually characterized by insufficient insulin secretion or use through excessive amounts of sugar in the blood and urine and symptoms of high blood sugar include frequent urination and increased thirst and increased hunger ${ }^{(2)}$. This increase in the percentage of blood glucose is due to the interaction between genetic and environmental factors ${ }^{(3)}$ "The disease can develop in a lifetime, but type 1 diabetes usually affects children and young people, and people with insulin need it every day" to control glucose levels in their blood. Without insulin, people with Type 1 diabetes will not be able to survive. Type 2 diabetes is the most common type ", which accounts for about $90 \%$ of all cases of diabetes ${ }^{(4-6)}$. In type 2 diabetes. Blood sugar is 
increased due to insufficient insulin production and the inability of the body to fully respond to insulin (insulin resistance) This type of sugar is more common in adults "but there are increasing infections of the disease seen in children, adolescents and younger adults" because of high levels of obesity, physical inactivity and malnutrition, the high levels of glucose in the blood constantly cause damage to blood vessels which affect the heart, eyes, kidneys, and nerves is considered as one of the main causes of cardiovascular disease, blindness and kidney failure $^{(7)}$. If left untreated diabetes can cause many complications ${ }^{(8)}$.

The condition of hyperglycemia and convulsions loss of consciousness and inflammation, the complications of chronic microvascular diseases are nephropathy, neuropathy, retinopathy, and diabetic foot diabetes is also associated with increased rates of cancer and physical disability ${ }^{(9-}$ ${ }^{11)}$ and depression ${ }^{(\mathbf{1 2})}$. These serious complications are on the run as a result of an increase in the oxidative stress of the living cell, which leads to an increase in the biological processes producing the oxidizing compounds consumed for the biological compounds of the defense, which are the antioxidants of trace elements. It was noted that there is a relationship between diabetes and trace elements according to several research studies ${ }^{(13)}$ In many cases a change in the metabolism of these minerals has occurred (14-17). The mechanisms proposed to enhance insulin function through trace elements activate insulin receptor sites ${ }^{(\mathbf{1 8})}$ acting as adjuvants or components of enzyme systems that participate in glucose metabolism ${ }^{(19)}$ and increase the sensitivity of insulin also act as an antioxidant to prevent oxidation of tissues (20) The most prominent feature of the metabolic process in diabetes is the abnormal concentration of blood glucose level ${ }^{(21)}$. The function of calcium is based on metabolism where calcium is a non-enzymatic antioxidant that Strengthening the body's defensive devices which eliminate the free radicals concentrated, where about $99 \%$ of the calcium in the bones and teeth and the remaining $1 \%$ is in the blood, the cells of the body perform important metabolic functions, Calcium ion contributes to diabetes by regulating the secretion of insulin from the B-Cells in the Lan-Cher Hans pancreatic islands in almost any cell type, "regulating the amount of calcium in cells is crucial to the normal functioning of many cellular processes, including metabolism, excretion, and signal stimulation through its pivotal role in activating the complex calcium-calmolin protein ${ }^{(22)}$, Calcium ion, is an essential intermediary within beta cells that play an important role in the secretion of insulinstimulating glucose ${ }^{(23,24,25)}$. And directly affects the secretion of insulin stimulating glucose ${ }^{(26)(27)(28)}$.

\section{Material and Methods}

\section{Research samples}

This study included 50 samples of diabetics, with their data recorded according to a questionnaire that included age, hereditary, and social status. The duration of infection was determined for the majority of patients from the onset of diabetes symptoms.

\section{Criteria for patient selection}

Individuals aged between (4-75) years who were of both sexes were selected for this study and were divided into two groups, control group A, and patients with diabetes for more than two years Group B, patients were selected based on some variables such as age groups, social status, and heredity.

\section{A-Age groups: -}

Patients were divided into three age groups 
1- The first category of age (4-20) years of both sexes and their concentration of ca was measured.

$2 \_$The _ The second category of age (21-50) years. 3 third category of age (51-75) years.

BSocial

status

1 - patients affected by the social situation number 28

2 - Laytharon patients with social status number 22

C - Genetics hereditary: is intended to study the condition of people with a family history of diabetes and patients were divided into two groups 1 - Patients with a family history (+) and their number

26

2 - Patients who do not have a family history( -) and their number 24

\section{Collect blood samples}

Blood samples were collected from the brachial vein by pulling out $5 \mathrm{~cm} 3$ and placed in a sterilized plastic tube free of anticoagulant to obtain serum.
Serum was obtained using the centrifuge. The process is performed at 3000 cycles/minute. kit by using the(UV-1100 spectrophotometer), a wavelength of $570 \mathrm{~nm}$ and a temperature of $37^{\circ} \mathrm{C} .20 \mu 1$ of the sample and $20 \mu \mathrm{l}$ of the standard were taken. And adjust the instrument to zero with distilled water, Mix and incubate for $5 \mathrm{~min}$.at room temperature, $37^{\circ} \mathrm{c}$, Read the absorbance of the samples and standard, against the blank the color is stable for at least 40 min.

This method has been used for its privacy, reliability, and simplicity.

\section{statistical}

analysis:

The statistical analysis program was used to evaluate the statistical groups for the ANOVA TEST, test in a significantly less significant difference to determine the effect of the moral factors and to determine the existence of significant differences using the LSD for the moral level ( $p$ $<.05)$.

\section{Result;}

Table (1) refers to the significant difference between the level of $\mathrm{Ca}$ in blood serum at different age groups.

\begin{tabular}{|c|c|}
\hline Rates of a proportion of Ca in serum with error standard & Age groups \\
\hline $1.05 \pm 0.18^{\mathrm{b}}$ & $4-20$ years \\
\hline $1.23 \pm 0.09^{\mathrm{a}}$ & $21-50$ years \\
\hline $0.17 \pm 0.03^{\mathrm{b}}$ & $51-75$ years \\
\hline
\end{tabular}

The small letter refers to a significant difference between them at level $p<(0.05)$. The value represents mean $\pm \mathrm{SE}$ 
Table (2) refers to the significant difference level of $\mathrm{Ca}$ in blood serum between diabetes patients and healthy groups.

\begin{tabular}{|c|c|}
\hline $\begin{array}{c}\text { Rates of a proportion of Ca in serum with error } \\
\text { standard }\end{array}$ & Groups \\
\hline $1.38 \pm 0.11^{\mathrm{b}}$ & Groups of patients with diabetes \\
\hline $1.46 \pm 0.55^{\mathrm{a}}$ & A healthy \\
\hline
\end{tabular}

The small letter refers to a significant difference between them at level $p<(0.05)$. The value represents mean $\pm \mathrm{SE}$.

Table (3) refers to the significant difference level of $\mathrm{Ca}$ and $\mathrm{k}$ in blood serum between social and without social cases effects groups.

\begin{tabular}{|c|c|}
\hline $\begin{array}{c}\text { Rates of a proportion of Ca in serum with error } \\
\text { standard }\end{array}$ & Groups \\
\hline $0.75 \pm 0.24^{\mathrm{b}}$ & $\begin{array}{c}\text { Group of patients affected by a } \\
\text { social situation }\end{array}$ \\
\hline $1.04 \pm 0.12^{\mathrm{a}}$ & $\begin{array}{c}\text { Group of patients does not affect } \\
\text { by a social situation }\end{array}$ \\
\hline
\end{tabular}

The small letter refers to a significant difference between them at level $p<(0.05)$. The value represents mean $\pm \mathrm{SE}$

Table (4) refers to the significant difference level of $\mathrm{Ca}$ and $\mathrm{k}$ in blood serum between patients have case history and patient have not to case history effects groups.

\begin{tabular}{|c|c|}
\hline $\begin{array}{c}\text { Rates of a proportion of Ca in serum with error } \\
\text { standard }\end{array}$ & Groups \\
\hline $0.81 \pm 0.11^{\mathrm{a}}$ & $\begin{array}{c}\text { Patients with a family history } \\
(+)\end{array}$ \\
\hline $0.50 \pm 0.19^{\mathrm{b}}$ & $\begin{array}{c}\text { Patients do not have } \\
\text { family history ( - ) }\end{array}$ \\
\hline
\end{tabular}

The small letter refers to a significant difference between them at level $p<(0.05)$. The value represents mean $\pm \mathrm{SE}$ 


\section{Mean of} values

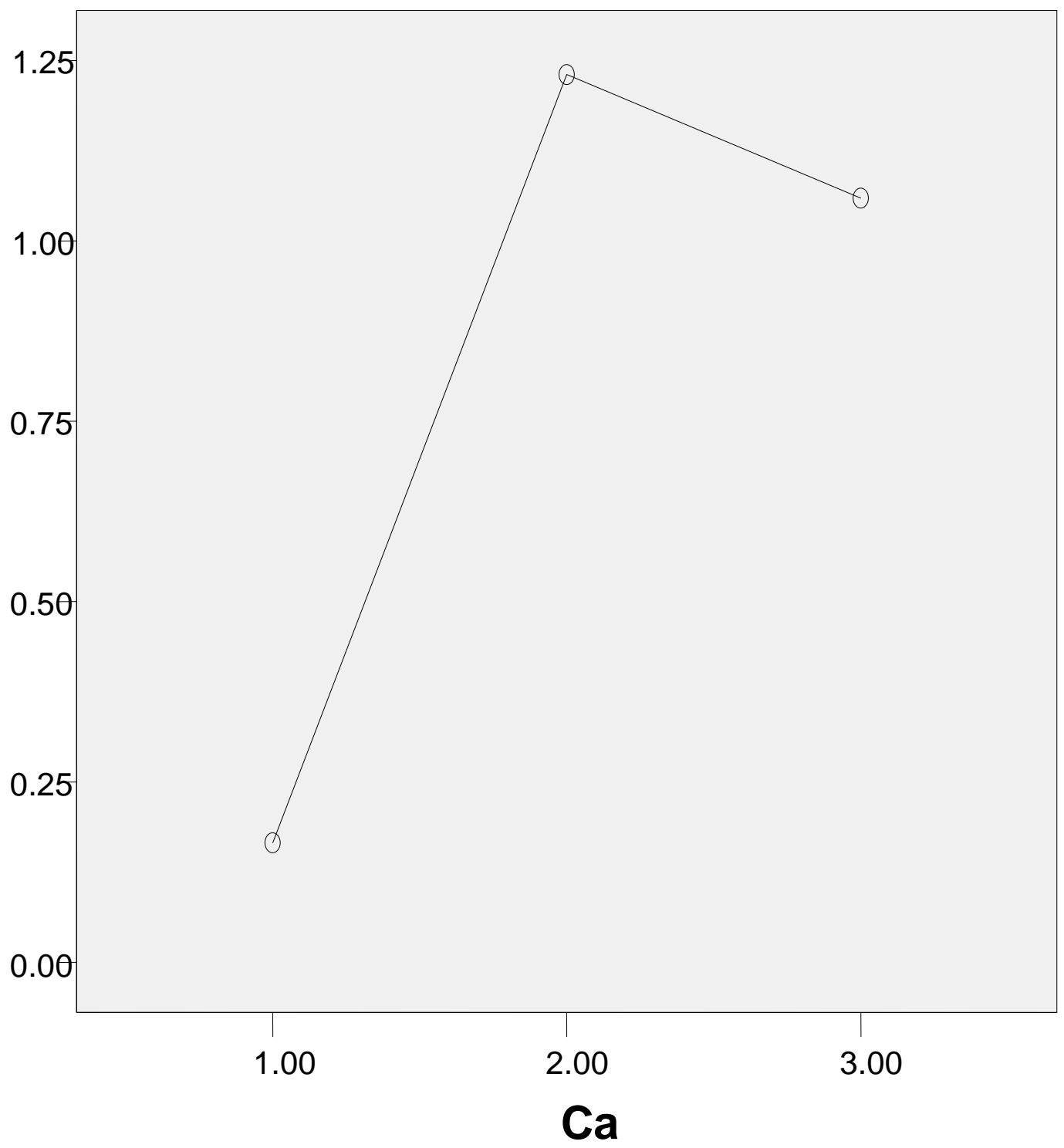

\section{Discussion}

People with Type 1 diabetes develop an autoimmune response, the body's immune system attacks insulinproducing beta cells in the pancreas, as a result, the body produces very little insulin, the causes of this destructive process remain poorly understood, but a combination of factors such as genetic susceptibility environmental stimuli, social conditions and some dietary factors ${ }^{(3)}$.

The underlying causes of type 2 diabetes are not fully understood. "But there is a strong relationship with overweight, obesity, and age, as well as race, family history, Malnutrition, physical inactivity, smoking, former history of hyperglycemia and the relationship between high consumption of sugar-sweetened drinks and the risk of developing type 2 diabetes ${ }^{(28-30)}$. And not to eat enough fruits, vegetables, whole grains, and dietary fibers rich in calcium, that the increase in diabetes type 2 is due to aging and economic development and increase consumption of foods that cause obesity ${ }^{(31)}$, where the results of the current study that the rate of total calcium concentration in $\mu \mathrm{g} / 100 \mathrm{ml}$ for blood samples of patients with diabetes $\mathrm{N}=50$ and three different age groups and for both $\left(1.38 \pm 0.11^{\mathrm{b}}\right) \mu \mathrm{g} / 100 \mathrm{ml}$ were less than the total calcium level in the healthy group serum $(\mathrm{N}=30)$ for the same age groups with concentrations of 
$\left(1.46 \pm 0.55^{\mathrm{a}}\right) \mu \mathrm{g} / 100 \mathrm{ml}$. This leads to a decrease in calcium levels due to their state of stress $\quad(32,8)$.

The differences were significant in the level of $p<0.05$ between diabetic and healthy patients. Several studies and studies were conducted that evaluated the concentration of calcium in the blood and its relationship to many diseases.

This study found that calcium concentration decreases with age in the case of healthy and sick people compared to middleaged and children. This decrease was observed in both sexes. The results of the current study for children under 20 years of age showed significant differences, as no evidence was found in this age group only because they have a genetic defect that is inherited stay with many studies ${ }^{(32-34)}$, as the results of the current study showed that the statistical analysis of the age group (21-50) year which indicates significant differences ( $p$ $<0.05)$ due to several factors including smoking, fear, and depression, as smokers are less committed with recommended self-care compared to nonsmokers. Smokers also tend to have erroneous and incorrect behaviors, including lack of physical activity and high-fat diets, including fruits and vegetables, and some medications ${ }^{(35-37)}$,. The results of the present study showed significant differences in the age group (51-75) years due to physical inactivity and lack of exercise, which lead to physiological dysfunction in glucose absorption, decrease in clotathione, and accumulation of leonic acid ${ }^{(39,40)}$, which leads to diabetes ${ }^{(41-43)}$. The results of the study showed that there were significant differences in people who had hereditary diabetes $\left(0.81 \pm 0.11^{\mathrm{a}}\right) \mu \mathrm{g} / 100 \mathrm{ml}$ than other patients $\left(0.50 \pm 0.19^{b}\right) \mu \mathrm{g} / 100 \mathrm{ml}$ and $\left.p<0.05\right)$. This is due to a genetic defect in the genome $\mathrm{e}^{(4,45-1)}$. The results of the present study also showed significant differences in the social conditions by $(p<0.05)$ due to exposure to tension and depression. Where the body secretes some hormones, such as adrenaline and cortisone, which works to raise the level of glucose in the blood in healthy people the body is a defensive plan to fight high blood sugar and thus maintain the rates of sugar fixed ${ }^{(46-47)}$.

\section{Conclusion}

One of the most serious consequences of diabetes is the increase of glucose blood level, resulting in a significant decrease in the concentration of the calcium element, and this cycle to increase the speed of the formation of oxidizing factors free radicals and peroxides and the entry of the pancreas cell in the case of serious oxidative stress due to the disorder of both calcium and activity of calcium, thus the disruption of the oxidative cycle of the reduction of plutonium, which leads to the exposure of tissues and organs to the attack of oxidizing factors and thus the possibility of defect and fragility in the bones and teeth in patients with diabetes, low blood calcium level in diabetic patients causes an imbalance in glucose transfer across the cell membrane and secretion of insulin from the pancreas.

\section{References;}

1- Davies JL, Kawaguchi Y, Bennett ST, et al. A genome-wide search for human type 1 diabetes susceptibility genes. Nature. 1994;371: 130-136 . DOI: $10.1038 / 371130 \mathrm{a} 0$.

2. Maahs DM, West NA, Lawrence JM, et al. Epidemiology of Type1 Diabetes. Endocrinol Metab Clin North Am 2010; 39: 481-97; DOI: http://dx.doi.org/10.1016/j. ecl.2010.05.011.

3. You WP, Henneberg M. Type 1 diabetes prevalence increasing globally and regionally: the role of natural selection and life expectancy at birth. BMJ Open Diabetes Res Amp Care 2016; 4; DOI: http://dx.doi.org/10.1136/ bmjdrc-2015000161.

4. Evans JM, Newton RW, Ruta DA, et al. Socioeconomic status, obesity, and prevalence of Type 1 and Type 2diabetes mellitus. Diabet Med J $\mathrm{Br}$ Assoc 2000; 17: 478-80; DOI: http://dx.doi.org/10.1046/j.14645491.2000.00309.

$\mathrm{x}$. 
5. Bruno G, Runzo C, Cavallo-Perin P, et al. Incidence of Type 1 and Type 2 Diabetes in Adults Aged 30-49 Years: The population-based registry in the province of Turin, Italy.Diabetes Care 2005; 28: 2613- 19; DOI: http://dx.doi.org/10.2337/ diacare.28.11.2613.

6. Holman N, Young B, Gadsby R.Current prevalence of Type 1 and Type 2 diabetes in adults and children in the UK.Diabet Med J Br Diabet Assoc 2015; 32: 1119-20; DOI: http://dx.doi.org/10.1111/dme.12791.

7. Cederholm J, Gudbjernsdottir S,Eliasson B, et al. Blood pressureand risk of cardiovascular diseasesin type 2 diabetes: further findingsfrom the Swedish National Diabetes Register )NDR-BP II(. J Hypertens 2012; 30: 2020-30; DOI: http://dx.doi.org/10.1097/HJH.0b013e32833c8b7 5

8- Changhwan Ahn, 1 Ji-Houn Kang,2 Eui-Bae Jeung $₫ 1$ Calcium homeostasis in diabetes mellitus. 2017 Sep; 18(3): 261-266. J Vet Sci

9. Shah AD, Langenberg C, Rapsomaniki E, et al. Type 2 diabetes and incidence of a widerange of cardiovascular diseases: acohort study in 1.9 million people The Lancet 2015; 385, S86.

10. Cardoso CRL, Salles GF. Gross proteinuria is a strong risk predictor for cardiovascular mortality in Brazilian type 2 diabetic patients. Braz J Med Biol Res 2008; 41: 674-80;

11. Davis WA, Knuiman MW, Davis TME. An Australian cardiovascular risk equation for type 2 diabetes: the Fremantle Diabetes Study. Intern Med J 2010; 40: 286-92;

12-. Ting RZ, Lau ES, Ozaki R, et al. High risk for cardiovascular disease in Chinese type 2 diabetic patients with major depression-a 7-year prospective analysis of the Hong Kong Diabetes Registry.J Affect Disord 2013; 149: 129-35;.

13- RK Murray, D Granner, P Mayes, V Rodwell. Harper's Biochemistry $(25$ th International Edition) (2000) Appleton and Lange, USA.

14- Powers MA. Handbook of Diabetes Nutritional Management. Aspen Publishers Inc. Maryland 1987; 195.

15-Chausmer AB. Zinc, insulin and diabetes. J Am College Nutr. 1998; 17: 109-14.

16 -Forrest $\mathrm{H}$ Nielsen. New essential trace elements for the life sciences. Biological Trace Element Research. 1990; 26-27 (1): 599-611.

17 - Nerlich AG, Sauer U, Kolm-Litty V, Wagner E, Koch M, Schleicher ED. Expression of glutamine: fructose-6-phosphate amidotransferase in human tissues: evidence for high variability and distinct regulation in diabetes. Diabetes, 1998; 47 : 170-178.

18] Vincent JB. Quest for the molecular mechanisms of chromium action and its relationship to diabetes. Nutr. Rev. 2000; 58: 6772. Journal of Clinical and Diagnostic Research. 2013 Sept, Vol-7(9): 1863-1865

19] Monika K. Waltr, Michael B. Zimmermann, Giatgen A. Spinas, Richard F. Hurrell. Low plasma magnesium in type 2 diabetes. Swiss Med Wkly 2003; 133: 289-92.

20 - Kruse-Jarres, J.D, M. Rukguaer. Trace Elements in Diabet Mellitus.Peculiarities and Clinical Validy of determinations of red blood cells. J Trace Elem. Med. Biol. 2000; 14: 21-27.

21- V Rai, U Iyer, I Mani, U V Mani. Serum Biochemical Changes in Insulin Dependent and 
Non-Insulin Dependent Diabetes Mellitus and their Role in the Development of Secondary Complications. Int. J. Diab. Dev. Countries 1997 ;17

22-Xiao Yu, Koji Murao, Yoshitaka Sayo, Hitomi Imachi, Wen M. Cao, The Role of Calcium/Calmodulin-Dependent Protein Kinase Cascade in Glucose Upregulation of Insulin Gene Expression ,Diabetes 2004 Jun; 53(6): 14751481.

23-Wollheim CB, Sharp GW: Regulation of insulin release by calcium. Physiol Rev 61: 914 -973, 1981.

24- Worley JF 3rd, McIntyre MS, Spencer B, Mertz RJ, Roe MW, Dukes ID: Endoplasmic reticulum calcium store regulates membrane potential in mouse islet beta-cells. J Biol Chem 269:14359-14362, 1994.

25- Wollheim C. B., Sharp G. W.(1981) Physiol. Rev. 61:914-973.

26-Meldolesi J, Pozzan T: The endoplasmic reticulum $\mathrm{Ca} 2+$ store: a view from the lumen. Trends Biochem Sci 23:10 -14, 1998.

27- Levy J., Gavin J. R. III., Sowers J. R.(1994) Am. J. Med. 96:260-273.

28- Imamura F, O'Connor $\mathrm{L}$, Ye $\mathrm{Z}$, et al. Consumption of sugar sweetened beverages, artificially sweetened beverages, and fruit juice and incidence of type 2 diabetes: systematic review, meta-analysis, and estimation of population attributable fraction. BMJ 2015; 351: h3576.

29. InterAct Consortium, Romaguera $\mathrm{D}$, Norat $\mathrm{T}$, et al. Consumption of sweet beverages and type 2 diabetes incidence in European adults: results from EPIC-InterAct. Diabetologia 2013; 56: 1520-30
30. Malik VS, Popkin BM, Bray GA, et al.Sugarsweetened beverages and risk of metabolic syndrome and type 2 diabetes: a metaanalysis. Diabetes Care 2010; 33:2477-83

31. Basu S, Yoffe P, Hills $\mathrm{N}$, et al. The Relationship of Sugar to Population-Level Diabetes Prevalence: An Econometric Analysis of Repeated Cross Sectional Data. PLoS ONE 2013; 8:e57873.

32. Pittas AG, Dawson-Hughes B, Li T, Van Dam RM, Willett WC, Manson JE, Hu FB. Vitamin D and calcium intake in relation to type 2 diabetes in women. Diabetes Care. 2006; 29:650-656.

33- DIAMOND Project Group Incidence and trends of childhood type 1 diabetes worldwide 1990-1999 .Diabet Med. 2006; 23:857-866.

34- Patterson CC, Dahlquist GG, Gyürüs E, et al. Incidence trends for childhood type 1 diabetes in Europe during 1989-2003 and predicted new cases 2005-20: a multicentre prospective registration study. Lancet .2009:2027; 373-2033.

35- Barrett JC, Clayton DG, Concannon P, et al . Genome-wide association study and meta-analysis find that over 40 loci affect risk of type 1 diabetes. Nat Genet. 2009; 41:703-707. doi:10-1038ng.381.

36-Eliasson B. Cigarette smoking and diabetes. Prog Cardiovasc Dis. 2003; 45:405 413.

37 - Yu MK, Lyles CR, Bent-Shaw LA, Young BA. Sex disparities in diabetes process of care measures and self-care in high-risk patients. Journal of diabetes research. 2013; 2013:575814.

38-Chiolero A, Wietlisbach V, Ruffieux C, Paccaud F, Cornuz J. Clustering of risk behaviors with cigarette consumption: A population-based survey. Prev Med. 2006; 42:348-53.

39. Kolka CM, Richey JM, Castro AV, Broussard JL, Ionut V, Bergman RN. Lipid-induced insulin 
resistance does not impair insulin access to skeletal muscle. Am J Physiol Endocrinol Metab. 2015

40- Iggman D, Arnlov J, Vessby B, Cederholm T, Sjogren P, Riserus U. Adipose tissue fatty acids and insulin sensitivity in elderly men. Diabetologia 2010; 53:850-7

41. Garvey, W. T., Huecksteadt, T. P. \& Birnbaum, M. J. (1989) Science 245, 60-63

42. Kahn, B. B., Charron, M. J., Lodish, H. F., Cushman, S. W. \&Flier, J. S. (1989) J. Clin. Invest. $84,404-411$

43. Strout, H. V., Vicario, P. P., Biswas, C., Saperstein, R., Brady, E. J., Pilch, P. F. \& Berger, J. (1990) Endocrinology (Baltimore) 126,27282732

44- $N$ Engl J Med. 2006 Aug 3; 355(5):456-66. Activating mutations in the ABCC8 gene in neonatal diabetes mellitus. Babenko AP(1), Polak M, Cavé H, Busiah K, Czernichow P, Scharfmann
$R$, Bryan J, Aguilar-Bryan L, Vaxillaire M, Froguel $P$. Author information: Department of Molecular and Cellular Biology, Baylor College.

45 - Prochazka, M., S. Lillioja, J. F. Tait, W. C. Knowler, D. M. Mott, M.

Spraul, P. H. Bennett, and C. Bogardus. 1993. Linkage of chromosomal markers on $4 \mathrm{q}$ with a putative gene determining maximal insulin action in Pima Indians.Diabetes. 42:514-519

46- Clouse RE,Lustman PJ,Freedland KE, Griffith LS, McGill JB ,Carney RM :Depression and coronary heart disease in women with diabetes. Psychosom Med 65:376-383, 2003 Diabetes pectrum,17:150-159,2004

47- Lustman PJ, Anderon RJ, Freedland KE, de Groot MK, Carney RM, Clouse RE Depression, and poor glycemic control: a meta analytic review of the literature. Diabetes Care 23: 934-942, 2000.

\section{Abstract in Arabic Language}

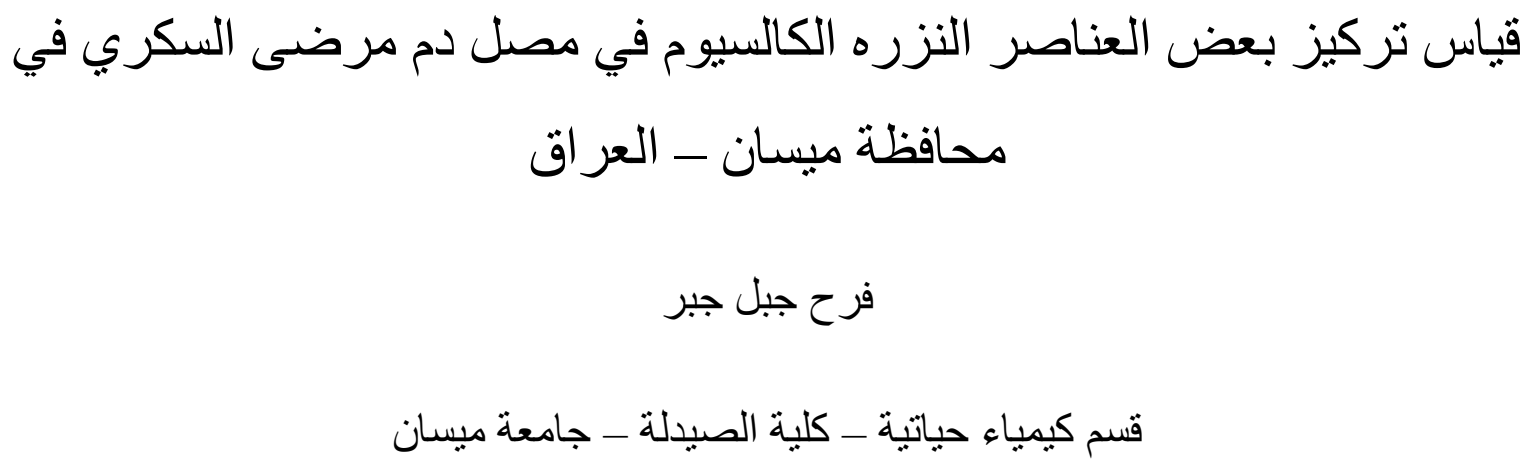

منهجية البحث: أجريت هذه الدر اسة لقياس تركيز بعض العناصر النزرة الكالسيوم و اشتملت الدراسة على 50 عينة تتر اوح أعمار هم من 4-75 سنة من معتادي مركز أمر اض الغدد الصماء في محافظة ميسان ر تم تم تقسيم المرضى الى ثثلاث فئات عمرية من عمر ( 20-4) سنة و الفئة الثانية من عمر ( 50-21) سنة و الفئة الثالثة من عمر ( 75-51)سنة من كلا الجنسين وتم تشخيص حالات السكري من قبل الاخصائين من خلال التحاليل المختبرية وبالتالي تحديد نمط الإصابة لدى جميع أفر اد هذه المجمو عة 
, وتحديد مدة الإصابة لغالبية المرضى من بداية ظهور أعر اض السكري بالمقارنة مع 30 عينة

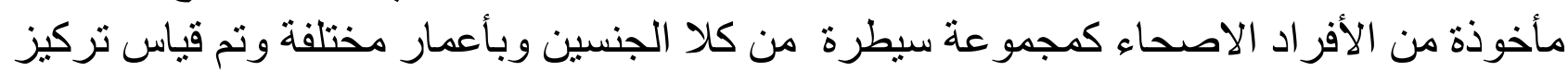
الكالسيوم للمرضى و الأصحاء.

أظهرت نتائج الدراسة أن معدل تركيز الكالسيوم الكلي بالميكروغرام / 100 مل لعينات دم

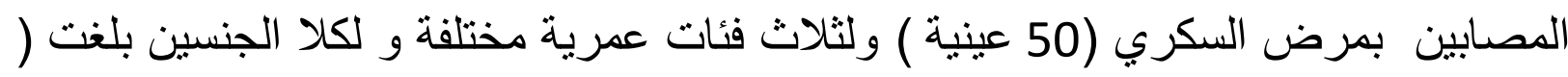

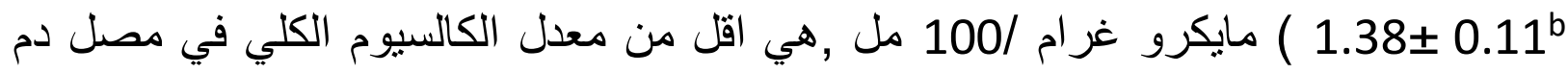

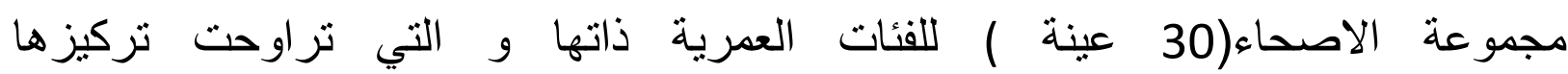

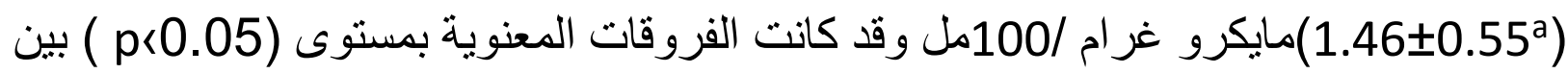

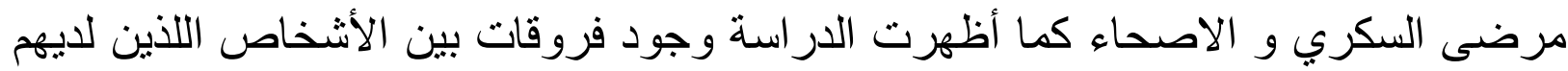
تاريخ عائلي للمرض (الور اثثة) اذ اظهر تركيز الكاليكيوم ( الأشخاص اللذين ليس لليهم تاريخ عائلي اذ اظهر تركيز الكالسيوم (0.50ـ0.19b

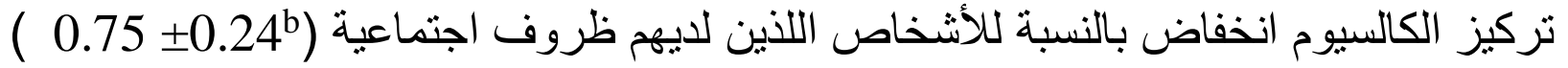
مقارنة مع مرضى ليس لديهم ظروف اجتماعية (1.04 1.0.1) . 